\title{
Lactic acid excretion by Streptococcus mutans
}

\author{
Stuart G. Dashper and Eric C. Reynolds
}

Biochemistry and

Molecular Biology Unit,

School of Dental Science, Faculty of Medicine,

Dentistry and Health

Sciences, The University of

Melbourne, 711 Elizabeth

Street, Melbourne, Victoria

3000, Australia
Author for correspondence: Eric C. Reynolds. Tel: +613341 0270. Fax: +6133410339.

e-mail: eric_reynolds.dental@muwaye.unimelb.edu.au

Lactic acid is the major end-product of glycolysis by Streptococcus mutans under conditions of sugar excess or low environmental pH. However, the mechanism of lactic acid excretion by $S$. mutans is unknown. To characterize lactic acid efflux in $S$. mutans the transmembrane movement of radiolabelled lactate was monitored in de-energized cells. Lactate was found to equilibrate across the membrane in accordance with an artificially imposed transmembrane $\mathrm{pH}$ gradient $(\Delta \mathrm{pH})$. The imposition of a transmembrane electrical potential $(\Delta \psi)$ upon de-energized cells did not cause an accumulation of lactate within the cell. The efflux of lactate from lactate-loaded, deenergized cells created a $\Delta \mathrm{pH}$, but did not create a $\Delta \psi$, indicating that lactate crosses the cell membrane in an electroneutral process, as lactic acid. $\Delta p H$ and $\Delta \psi$ were determined by the transmembrane equilibration of $\left[{ }^{14} \mathrm{C}\right]$ benzoic acid and $\left[{ }^{14} \mathrm{C}\right]$ tetraphenylphosphonium ion (TPP), respectively. The presence of a membrane carrier for lactic acid in S. mutans was suggested by counterflow. Enzymic determination of the intra- and extracellular lactate concentrations of S. mutans cells glycolysing at $\mathrm{pH}_{\mathrm{o}} \mathbf{6 . 8}$ and 5.5 showed that lactate distributed across the cell membrane in accordance with the equation $\Delta \mathrm{pH}=$ log[lact $]_{f} /[\text { lact }]_{{ }_{0}}$. The addition of high extracellular concentrations of lactate to glycolysing $S$. mutans at acidic $\mathrm{pH}$ resulted in a fall in $\Delta \mathrm{pH}$ and a subsequent decrease in glycolysis. The fall in $\triangle \mathrm{pH}$ was attributed to the $F_{1} F_{0}$ ATPase being unable to raise the $\mathrm{pH}_{\mathrm{i}}$ back to its initial level due to the build up of lactate anion within the cell creating a large $\Delta \psi$. The increase in $\Delta \psi$ resulted in the overall proton motive force remaining constant at about $-110 \mathrm{mV}$. The results demonstrate that lactate is transported across the cell membrane of $S$. mutans as lactic acid in an electroneutral process that is independent of metabolic energy and as such has important bioenergetic implications for the cell.

Keywords: lactate, intracellular $\mathrm{pH}$, dental caries, Streptococcus mutans, glycolysis

\section{INTRODUCTION}

Dental caries is initiated via the production of organic acids by certain plaque bacteria that lower the $\mathrm{pH}$ at the tooth surface and cause the demineralization of tooth enamel. Streptococcus mutans has been implicated as one of the major odontopathogens of human dental plaque due to its consistent clinical association with dental caries (Loesche, 1986). The pathogenicity of S. mutans relates to its ability to rapidly ferment sugar to lactic acid under the low $\mathrm{pH}$ conditions required to initiate caries (Loesche,

Abbreviations : $\Delta \mathrm{pH}$, transmembrane $\mathrm{pH}$ gradient; $\mathrm{pH}_{\mathrm{i}}$, intracellular $\mathrm{pH}$; $\mathrm{pH}_{0}$, extracellular $\mathrm{pH}$; [lact $]_{\mathrm{i}}$, intracellular lactate concentration; [lact] extracellular lactate concentration; $\Delta \psi$, transmembrane electrical potential; pmf, proton motive force; TPP, tetraphenylphosphonium ion.
1986; Tanzer et al., 1969). Geddes (1975) has demonstrated that the fall in plaque $\mathrm{pH}$ is due largely to lactic acid production by plaque bacteria.

S. mutans has no respiratory chain and produces ATP via glycolysis; under conditions of glucose excess lactate is the major end-product of this metabolism (Carlsson \& Griffith, 1974; Yamada \& Carlsson, 1975). Upon ingestion of food the level of sugar available to oral bacteria may increase from the normal resting level of $5-40 \mu \mathrm{M}$ of salivary secretions (Kelsay et al., 1972) to $5-40 \mathrm{mM}$ (Carlsson, 1984). Under these conditions the S. mutans fermentation pattern will shift from the production of mixed acid end-products to lactic acid (Yamada \& Carlsson, 1975). The enzymic mechanisms of this shift in fermentation patterns are well understood (Carlsson, 
1984; Yamada, 1987); however, the fate of the intracellularly produced lactic acid has received little attention.

Konings and colleagues (Michels et al., 1979; Otto et al., 1980, 1982; ten Brink \& Konings, 1980) have provided evidence for an 'energy recycling model' in Lactococcus lactis where the lactate ion, which is impermeable to the cell membrane, leaves the cell via a membrane carrier in symport with more than one proton. The energy recycling model is an extension of the chemiosmotic model presented by Mitchell (1963) and postulates that carriermediated excretion of end-products can lead to the generation of an electrochemical gradient across the cell membrane, thereby providing energy to the cell. Generation of an electrical potential can only be achieved if lactate leaves the cell with more than one proton.

In this investigation the process of lactate efflux from $S$. mutans was elucidated. The transmembrane movement of radiolabelled lactate under a variety of conditions and the measurement of lactate in glycolysing cells led to the conclusion that lactate leaves the cell as lactic acid in an electroneutral, carrier-mediated process that is energy independent. This has important consequences for the bioenergetics of the cell.

\section{METHODS}

Bacterial strain and culture conditions. Streptococcus mutans Ingbritt (Krasse, 1966; Linzer, 1976) was stored in 30\% glycerol broth at $-20^{\circ} \mathrm{C}$. The strain was checked regularly according to the criteria of Hardie \& Bowden (1976). Bacteria were grown as batch cultures at $37^{\circ} \mathrm{C}$ in TYE growth medium as described previously (Dashper \& Reynolds, 1990, 1992). Cells were harvested at mid-exponential phase by centrifugation $(1500 \mathrm{~g}$, $15 \min , 4^{\circ} \mathrm{C}$ ).

Glycolytic activity. Cells were washed twice with fermentation minimal medium (FMM, Dashper \& Reynolds, 1990) and resuspended in FMM to give a cell density of $1.25 \mathrm{mg}$ dry wt cells $\mathrm{ml}^{-1}$. Glycolytic activity was determined in a $\mathrm{pH}$ stat as described previously (Dashper \& Reynolds, 1990). The cell suspension was maintained at the desired $\mathrm{pH}$ by the automatic addition of a volumetric standard titrant $(0.1 \mathrm{M} \mathrm{KOH})$. Glycolytic activity was expressed as $\mathrm{nmol} \mathrm{H}^{+}$neutralized (mg dry wt cells) ${ }^{-1} \mathrm{~min}^{-1}$. The dry weight of cells was determined by filtering $1.0 \mathrm{ml}$ samples of the cell suspension through dry, preweighed $0.2 \mu \mathrm{m}$ polycarbonate filters supported on Whatman $\mathrm{GF} / \mathrm{A}$ filters. The intracellular water volume was 1.69 $\pm 0.07 \mu \mathrm{l}$ (mg dry wt cells) ${ }^{-1}$ (Dashper \& Reynolds, 1990).

Lactate transmembrane movement assay. Lactate transmembrane movement assays were conducted at $37^{\circ} \mathrm{C}$ in a pH stat. After the addition of $\left[{ }^{14} \mathrm{C}\right]$ lactate $\left[0.025-1.000 \mathrm{Ci} \mathrm{mol}{ }^{-1}\right.$ $\left.\left(1 \mathrm{Ci}=3.7 \times 10^{10} \mathrm{~Bq}\right)\right]$ under the described conditions (see below), samples (usually $2 \mathrm{mg}$ dry wt cells) were centrifuged $(15000 \mathrm{~g}, 15 \mathrm{~s})$ through a silicon oil mixture $(43: 57, \mathrm{v} / \mathrm{v}$, of 550 and 556 Dow Corning silicon fluids) with a specific gravity of $1.03 \mathrm{~g} \mathrm{ml}^{-1}$ (Bakker \& Harold, 1980). Extracellular lactate $\left([\mathrm{lact}]_{\mathrm{o}}\right)$ was quantified by determining the radioactivity in a $10 \mu \mathrm{l}$ sample of the supernatant. Radioactivity was measured in a liquid scintillation counter after sample digestion in NCS and suspension in OCS (Amersham). Extracellular and total water volumes in the cell pellet were determined in parallel experiments using $\left[{ }^{14} \mathrm{C}\right]$ polyethylene glycol $\left(\left[{ }^{14} \mathrm{C}\right] \mathrm{PEG}\right)$ and tritiated water, respectively. From these data the intracellular concentration of $\left[{ }^{14} \mathrm{C}\right]$ lactate $\left([\text { lact }]_{\mathrm{i}}\right.$ ) could be calculated.
Intracellular $\mathrm{pH}$ and transmembrane electrical potential. Intracellular $\mathrm{pH}\left(\mathrm{pH}_{\mathrm{i}}\right)$ was determined by the distribution of the weak acid, $\left[{ }^{14} \mathrm{C}\right]$ benzoic acid $\left(120 \mathrm{Ci} \mathrm{mol}{ }^{-1}, 2 \mu \mathrm{M}\right.$ final concentration) across the cell membrane as described previously (Dashper \& Reynolds, 1990, 1992), except that cells were separated from the medium by centrifugation through silicon oil (see above) and not filtration. Cellular adsorption of $\left[{ }^{14} \mathrm{C}\right]$ benzoic acid was determined using cells treated with $20 \mu \mathrm{M}$ gramicidin.

The transmembrane electrical potential $(\Delta \psi)$ was measured by the transmembrane equilibration of $\left[{ }^{14} \mathrm{C}\right]$ tetraphenylphosphonium ion $\left(\left[{ }^{14} \mathrm{C}\right] \mathrm{TPP} ; 20 \mathrm{Ci} \mathrm{mol}^{-1}, 5 \mu \mathrm{M}\right.$ final concentration). Centrifugation through silicon oil, as described above, was used to separate cells from the medium. The amount of $\left[{ }^{14} \mathrm{C}\right] \mathrm{TPP}$ adsorbed onto the cells was determined in the presence of $100 \mathrm{mM} \mathrm{KCl}$ and $100 \mathrm{mM} \mathrm{NaCl}$ (Dashper \& Reynolds, 1990).

Imposed $\mathbf{\Delta p H}$ in de-energized cells. After incubation in $50 \mathrm{mM}$ $\mathrm{K}^{+} \mathrm{FMM}$ ( $\mathrm{pH} 7 \cdot 5,40 \mathrm{~min}$ ), a $S$. mutans cell suspension was washed twice (to remove lactate) and resuspended in the same buffer to give a cell density of $5 \mathrm{mg}$ dry $w \mathrm{t} \mathrm{ml}^{-1}$. Either $\left[{ }^{14} \mathrm{C}\right]$ lactate $\left(1.000\right.$ or $\left.0.025 \mathrm{Ci} \mathrm{mol}^{-1}\right)$, to give a final concentration of 5 or $200 \mathrm{mM}$, or $\left[{ }^{14} \mathrm{C}\right]$ benzoic acid (see above) was added to an aliquot of the cell suspension. After 2 min the $\mathrm{pH}$ was rapidly lowered to about 5.4 by the addition of $0.5 \mathrm{M} \mathrm{HCl}$. Samples were centrifuged through silicon oil and [lact $]_{0}$, [lact $]_{i}$ and $\mathrm{pH}_{\mathrm{i}}$ were determined as described above.

Imposed $\Delta \psi$ in de-energized cells. A $\Delta \psi$ was generated in deenergized cells essentially as described by Otto et al. (1980). Briefly, cells were incubated $(40 \mathrm{~min})$ in $100 \mathrm{mM}$ Tris $/ \mathrm{HCl}$ buffer $(\mathrm{pH} \mathrm{7.0)}$ containing $200 \mathrm{mM} \mathrm{KCl}$. After incubation the suspension was washed (to remove lactate) and resuspended in the same buffer to give a cell density of $90 \mathrm{mg}$ dry wt $\mathrm{ml}^{-1}$. Valinomycin was then added to the cell suspension to a final concentration of $20 \mu \mathrm{M}$ and the cell suspension was incubated on ice for $40 \mathrm{~min}$. Samples of the cell suspension were diluted 100 -fold into $100 \mathrm{mM}$ Tris $/ \mathrm{HCl}$ buffer $(\mathrm{pH} \mathrm{7.0)}$ containing $10 \mu \mathrm{M}$ valinomycin and $5 \mathrm{mM}\left[{ }^{14} \mathrm{C}\right]$ lactate $\left(1 \cdot 0 \mathrm{Ci} \mathrm{mol}^{-1}\right)$ with $200 \mathrm{mM} \mathrm{NaCl}$. Samples were centrifuged through silicon oil at specified time intervals and [lact $]_{0}$ and [lact $]_{i}$ were determined as described above. $\Delta \psi$ was determined using $\left[{ }^{14} \mathrm{C}\right] \mathrm{TPP}$ as described above.

Lactate efflux from de-energized, lactate-loaded cells. Cells were washed and resuspended in a $200 \mathrm{mM}$ potassium phosphate buffer containing $200 \mathrm{mM}$ potassium lactate $(\mathrm{pH} 7 \cdot 5)$ to give a final cell density of $4 \mathrm{mg} \mathrm{dry} \mathrm{wt} \mathrm{ml}^{-1}$. The cell concentrate was incubated at $\mathrm{pH} 7.5$ and $37^{\circ} \mathrm{C}$ for $40 \mathrm{~min}$, then divided into $1 \mathrm{ml}$ aliquots, centrifuged $\left(1500 \mathrm{~g}, 4^{\circ} \mathrm{C}, 15 \mathrm{~min}\right)$ and the supernatant carefully removed. The cell pellet was resuspended in $200 \mathrm{mM}$ potassium phosphate buffer containing $200 \mathrm{mM} \mathrm{KCl}$ $(\mathrm{pH} 7 \cdot 5)$ and either $\left[{ }^{14} \mathrm{C}\right]$ benzoic acid or $\left[{ }^{14} \mathrm{C}\right] \mathrm{TPP}$. Samples were centrifuged through silicon oil at indicated time intervals and $\Delta \mathrm{pH}$ and $\Delta \psi$ determined as described above. A control where the cell pellet was resuspended into $200 \mathrm{mM}$ potassium phosphate buffer containing $200 \mathrm{mM}$ potassium lactate was conducted to account for non-specific binding of the radiolabel. This method of cell pellet resuspension gave a dilution factor of $91: 1$ as determined in parallel experiments by $\left[{ }^{14} \mathrm{C}\right] \mathrm{PEG}$.

Lactate counterflow. Counterflow experiments were conducted using a modification of the method of Maloney et al. (1975). The cell suspension was washed and resuspended in $50 \mathrm{mM}$ potassium FMM containing $400 \mathrm{mM}$ lactate and $20 \mu \mathrm{M}$ gramicidin, and incubated at $\mathrm{pH} 5.5,37^{\circ} \mathrm{C}$ for $30 \mathrm{~min}$. The $\mathrm{pH}$ was then raised to 7.5 and the cells incubated for a further $10 \mathrm{~min}$. After centrifugation, the supernatant was carefully removed by 
suction and the tube wall wiped of liquid. To start the assay the cell pellet was rapidly resuspended in $100 \mathrm{mM}$ Tris/ $\mathrm{HCl}$ buffer $\mathrm{pH} 7.5$ containing $20 \mu \mathrm{M}$ gramicidin and $1 \mathrm{mM}\left[{ }^{14} \mathrm{C}\right]$ lactate

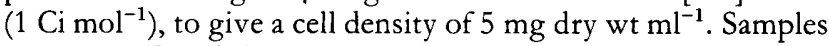
were centrifuged through silicon oil at indicated time intervals and [lact $]_{0}$ and $[\text { lact }]_{i}$ were determined as described above. An identical procedure was used for the control except that lactate was replaced with $400 \mathrm{mM} \mathrm{KCl}$ in the incubation step.

Enzymic lactate determination. Cells were washed and incubated in $50 \mathrm{mM} \mathrm{K} \mathrm{K}^{+} \mathrm{FMM}$ for $40 \mathrm{~min}$ to deplete endogenous energy sources, then washed and resuspended to give a cell

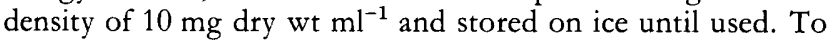
start the assay a glucose solution (final concentration $20 \mathrm{mM}$ ) was added to a sample of the cell suspension in the $\mathrm{pH}$ stat (pH 6.8 or 5.5$)$. At indicated times samples were filtered through $0 \cdot 2 \mu \mathrm{m}$ polycarbonate filters, on ice, without washing. The filters were immediately placed in $0.4 \mathrm{ml} 5 \%(\mathrm{v} / \mathrm{v})$ perchloric acid, vortexed and incubated overnight at $4{ }^{\circ} \mathrm{C}$. A sample was removed and centrifuged to remove cell debris. Lactate was measured in the supernatant by a modification of the methods of Horn \& Bruns (1956) and Cohen \& Noell (1960). An aliquot of $100 \mu$ of neutralized sample (suitably diluted) was added to $340 \mu \mathrm{l}$ of reaction mixture. The reaction mixture contained, $3 \mathrm{mg} \beta$-NAD ml $\mathrm{m}^{-1}, 200$ units lactic dehydrogenase $\mathrm{ml}^{-1}$ (EC 1.1.1.27, Sigma), $0.45 \mathrm{mM}$ semicarbazide hydrochloride and $300 \mathrm{mM}$ CHES buffer, $\mathrm{pH} 10^{\circ} 0$. This was incubated at $37^{\circ} \mathrm{C}$ for $2 \mathrm{~h}$ at which time the conversion of lactate to pyruvate was complete. Lactate concentration was determined spectrophotometrically at $340 \mathrm{~nm}$ by monitoring the conversion of NAD to NADH. The amount of extracellular water trapped on the filter was determined gravimetrically using duplicate samples. [lact $]_{i}$ was calculated by subtracting [lact $]_{0}$ from the total on the filter.

\section{RESULTS}

\section{Lactate transmembrane movement}

A $\Delta \mathrm{pH}$ was imposed on de-energized cells of $S$. mutans by rapidly lowering the $\mathrm{pH}_{0}$ from $7 \cdot 5$ to $5 \cdot 4$. This produced a $\Delta \mathrm{pH}$ (interior alkaline) of 1.05 units, equivalent to a proton motive force (pmf) of $-64.6 \mathrm{mV}$ (Fig. 1). In the presence of $5 \mathrm{mM}$ lactate a rapid influx of lactate occurred when the $\Delta \mathrm{pH}$ was imposed, leading to maximal in-

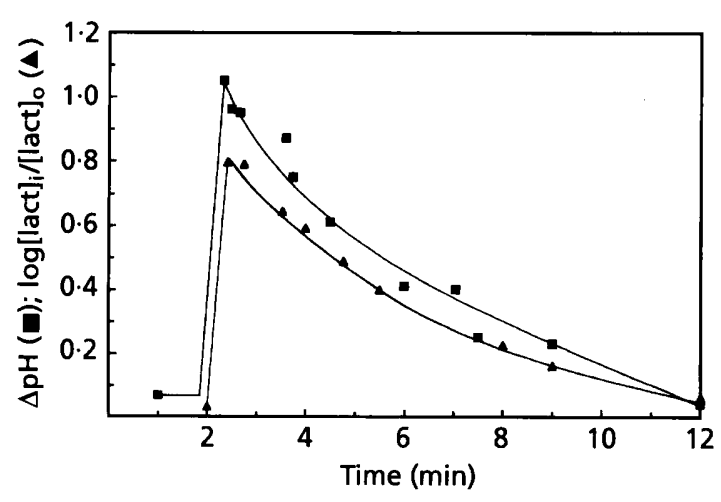

Fig. 1. Intracellular accumulation of $\left[{ }^{14} \mathrm{C}\right]$ lactate $(\boldsymbol{\Lambda})$ by deenergized cells of $S$. mutans in response to an imposed $\Delta \mathrm{pH}$ ( $\square$ ). The imposed $\Delta \mathrm{pH}$ was produced by rapidly lowering the $\mathrm{pH}_{0}$ with $\mathrm{HCl}$ after $2 \mathrm{~min}$. The $\Delta \mathrm{pH}$ was measured by the transmembrane equilibration of $\left[{ }^{14} \mathrm{C}\right]$ benzoic acid.

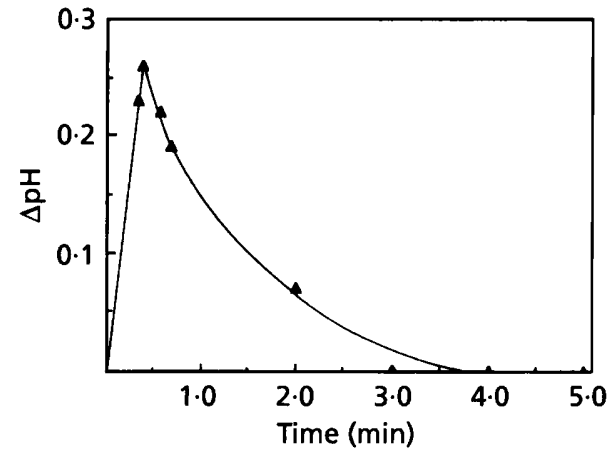

Fig. 2. Generation of a $\Delta \mathrm{pH}$ in de-energized, lactate-loaded cells of $S$. mutans by the efflux of lactic acid. Cells were loaded with $200 \mathrm{mM}$ lactate prior to dilution in a lactate-free buffer at time zero.

tracellular accumulation $\left([\text { lact }]_{\mathrm{i}}:[\text { lact }]_{\mathrm{o}}=6 \cdot 25: 1\right.$; Fig. 1). $[\text { lact }]_{\mathrm{i}}$ decreased as the imposed $\Delta \mathrm{pH}$ decayed and after 10 min the $[\text { lact }]_{i}:[\text { lact }]_{\mathrm{o}}$ ratio had returned to about $1: 1$ by which time the $\Delta \mathrm{pH}$ was zero. In the presence of $200 \mathrm{mM}$ lactate little intracellular accumulation of lactate occurred as the rapid movement of lactic acid into the cell at this high [lact] $]_{0}$ caused the collapse of the imposed $\Delta \mathrm{pH}$.

The efflux of lactate from lactate-loaded, de-energized cells of $S$. mutans resuspended at $\mathrm{pH} 7 \cdot 0$ also resulted in the formation of a $\Delta \mathrm{pH}$ (Fig. 2). However, no $\Delta \psi$ was formed under identical conditions of lactate efflux from lactateloaded, de-energized cells.

To investigate whether a $\Delta \psi$ would drive lactate accumulation, $\mathrm{K}^{+}$-loaded, de-energized cells of $S$. mutans were treated with valinomycin, in a medium containing low potassium at $\mathrm{pH} 7 \cdot 0$. This treatment produced a $\Delta \psi$ of $-62 \mathrm{mV}$ as measured by $\left[{ }^{14} \mathrm{C}\right] \mathrm{TPP}$ transmembrane equilibration. The imposition of this $\Delta \psi$ resulted in no intracellular accumulation of lactate. This was confirmed by conducting a similar experiment also at $\mathrm{pH} 7.0$ in which valinomycin-treated, de-energized cells suspended in a high potassium medium were diluted 100 -fold in media with no potassium containing valinomycin. This treatment produced a $\Delta \psi$ of $-120 \mathrm{mV}$ and also resulted in no intracellular accumulation of lactate.

\section{Lactate counterflow}

The transient intracellular accumulation of extracellularly added $\left[{ }^{14} \mathrm{C}\right]$ lactate within de-energized lactate-loaded cells of $S$. mutans demonstrated that counterflow did occur (Fig. 3), thereby suggesting the presence of a membrane carrier for lactic acid. The addition of $\left[{ }^{14} \mathrm{C}\right]$ lactate to control cells that were not lactate-loaded resulted in only the rapid transmembrane equilibration of the radiolabel across the cell membrane (Fig. 3). The presence of a membrane carrier for lactic acid is consistent with the exceedingly rapid transmembrane equilibration of radiolabelled lactate in de-energized cells that occurred over a wide range of concentrations. 


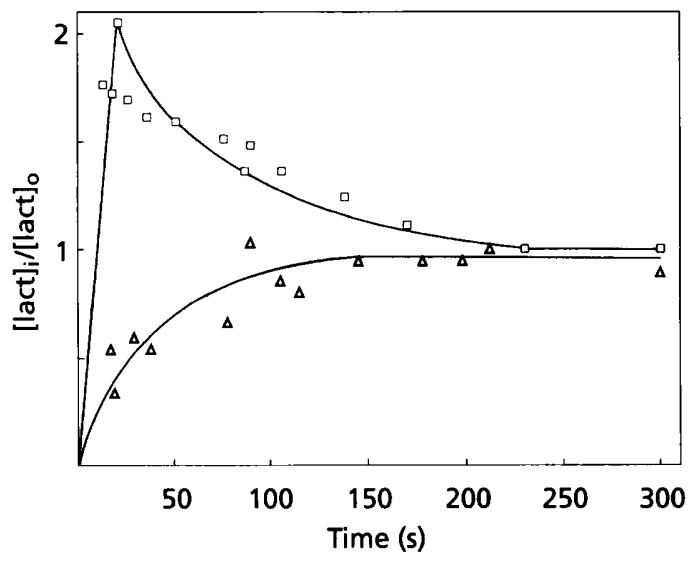

Fig. 3. Lactic acid counterflow in de-energized cells of $S$. mutans. Cells were incubated with either $400 \mathrm{mM}$ potassium lactate $(\square)$ or $400 \mathrm{mM} \mathrm{KCl}(\triangle)$ prior to centrifugation and suspension in buffer containing $5 \mu \mathrm{M}\left[{ }^{14} \mathrm{C}\right]$ lactate at time zero.

\section{Effect of lactate on $\mathrm{pH}_{\mathrm{i}}$ and glycolysis}

In a dense suspension of $S$. mutans cells (about $10 \mathrm{mg}$ dry wt cells $\mathrm{ml}^{-1}$ ) glycolysing at $\mathrm{pH}_{0} 5 \cdot 5$,[lact $]_{\mathrm{i}}$ and [lact $]_{\mathrm{o}}$ were determined enzymically. Lactate rapidly built up within the cell over the first 3 min maintaining an intracellular to extracellular concentration ratio of about $24: 1$. This ratio then began to decrease such that at $6 \mathrm{~min}$ after glucose addition it had fallen to about 16:1 (Table 1). Over the same time period the $\Delta \mathrm{pH}$, as measured by the transmembrane equilibration of radiolabelled benzoic acid, fell from $1 \cdot 32$ to $1 \cdot 18$. These results correlate well with the predicted $\Delta \mathrm{pH}$ assuming that lactate distributed across the cell membrane in accordance with the equation $\Delta \mathrm{pH}=\log [\text { lact }]_{\mathrm{i}} /[\text { lact }]_{\mathrm{o}}$ (Table 1$)$. The $\Delta \mathrm{pH}$ continued to fall such that at $25 \mathrm{~min}$ after glucose addition it was 0.91 and at $30 \mathrm{~min}$ it was 0.87 . There was a consequent decrease in glycolytic activity over the same time period. In more dilute cell suspensions (1-2 $\mathrm{mg}$ dry wt cells $\mathrm{ml}^{-1}$ ) of $S$. mutans glycolysing at $\mathrm{pH}_{\mathrm{o}} 5.5$ this fall in $\mathrm{pH}_{\mathrm{i}}$ and decrease in glycolytic activity was not seen, as [lact]。 obviously did not increase as rapidly as in denser cell suspensions.

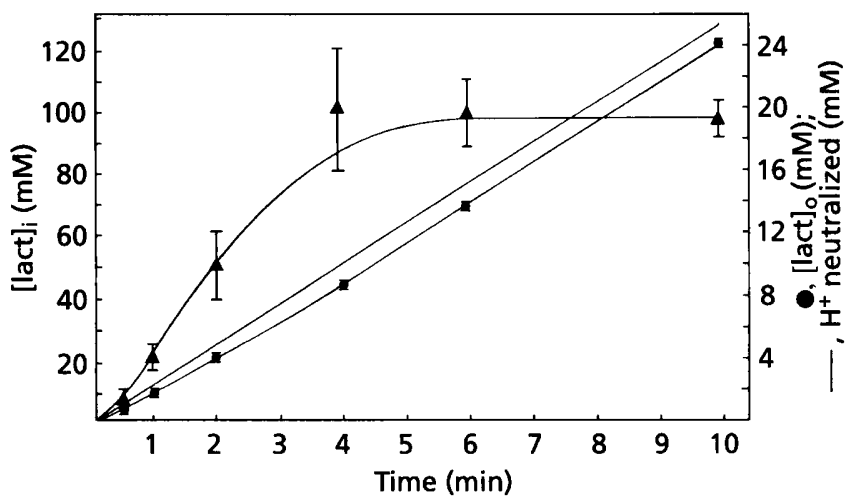

Fig. 4. $[\text { lact }]_{i}(\boldsymbol{\Delta}),[\text { lact }]_{\circ}(O)$ and rate of acid production $(-)$ in cells of $S$. mutans glycolysing at $\mathrm{pH}_{0} 6.8$. Lactate was enzymically determined. Time zero refers to the addition of glucose. Data points represent the mean \pm SD of three determinations.

In a dense suspension of $S$. mutans cells glycolysing at $\mathrm{pH}_{\mathrm{o}}$ 6.8 similar results were obtained to those at $\mathrm{pH}_{\mathrm{o}} 5.5$ (Fig. 4). [lact $]_{i}$ increased over the first 4-5 min of glycolysis to $95 \mathrm{mM}$. After this time the $[\mathrm{lact}]_{\mathrm{i}}$ remained fairly constant whilst the ratio of $[\mathrm{lact}]_{\mathrm{i}}$ to $[\mathrm{lact}]_{\mathrm{o}}$ fell from 11.4 at $4 \mathrm{~min}$ to 3.9 at $10 \mathrm{~min}$. The $\Delta \mathrm{pH}$ of $S$. mutans cells was measured under similar experimental conditions and found to fall from 0.86 at 4 min to 0.50 at $10 \mathrm{~min}$; it continued to fall as glycolysis progressed such that at $50 \mathrm{~min}$ it was $0 \cdot 14$. The fall in $\mathrm{pH}_{\mathrm{i}}$ at this $\mathrm{pH}_{0}$ had little effect on glycolytic activity.

\section{Effect of added extracellular lactate on $\mathrm{pH}_{\mathrm{i}}$ and glycolysis}

When $100 \mathrm{mM}$ potassium lactate was added to $S$. mutans glycolysing at $\mathrm{pH}_{\mathrm{o}} 5 \cdot 5$ there was an immediate decrease in $\mathrm{pH}_{\mathrm{i}}$ and glycolytic activity. Based on the fall in $\mathrm{pH}_{\mathrm{i}}$, an inhibition of glycolytic activity of $38 \%$ was predicted from previous work (Dashper \& Reynolds, 1992). The observed inhibition of $40 \%$ corresponds well with the predicted result, indicating that the decrease in glycolytic activity is due entirely to the fall in $\mathrm{pH}_{\mathrm{i}}$. There was a

Table 1. [lact $]_{i,}[\text { lact }]_{0}$ and $\mathrm{pH}_{\mathrm{i}}$ of $S$. mutans cells glycolysing at a $\mathrm{pH}_{0}$ of 5.5 in $50 \mathrm{mM} \mathrm{K}^{+}$ FMM

\begin{tabular}{|c|c|c|c|c|c|}
\hline $\begin{array}{l}\text { Time after } \\
\text { glucose } \\
\text { addition (min) }\end{array}$ & {$[\text { lact }]_{i}(\mathrm{mM})^{*}$} & {$[\text { lact }]_{0}(\mathrm{mM})^{*}$} & {$\left[\right.$ lact $_{\mathrm{i}} /\left[\mathrm{llact}_{\mathrm{o}}\right.$} & $\begin{array}{c}\text { Predicted } \\
\Delta \mathrm{pH} \dagger\end{array}$ & $\begin{array}{c}\text { Measured } \\
\Delta \mathrm{pH} \ddagger(\text { mean } \\
\pm \mathrm{SD}, n=4)\end{array}$ \\
\hline 2 & $75 \cdot 2$ & $3 \cdot 2$ & $23 \cdot 5$ & $1 \cdot 37$ & $1.32 \pm 0.03$ \\
\hline 3 & $114 \cdot 3$ & $4 \cdot 8$ & $23 \cdot 8$ & $1 \cdot 37$ & - \\
\hline 4 & 133.9 & 6.7 & $19 \cdot 9$ & $1 \cdot 30$ & $1 \cdot 22 \pm 0 \cdot 02$ \\
\hline 6 & $165 \cdot 9$ & $10 \cdot 5$ & $15 \cdot 8$ & $1 \cdot 20$ & $1 \cdot 18 \pm 0 \cdot 02$ \\
\hline
\end{tabular}

* Lactate was measured enzymically.

† Based on the equation $\log [\text { lact }]_{\mathrm{i}} /[\text { lact }]_{\mathrm{o}}=\Delta \mathrm{pH}$.

$\ddagger$ Determined by the transmembrane equilibration of $\left[{ }^{14} \mathrm{C}\right]$ benzoic acid. 
Table 2. The effect of extracellular lactate on the transmembrane forces maintained by S. mutans cells glycolysing at a $\mathrm{pH}_{0}$ of 5.5 in $50 \mathrm{mM} \mathrm{K}^{+} \mathrm{FMM}$.

\begin{tabular}{|lccc|}
\hline & $\Delta \mathbf{p H}^{*}$ & $\Delta \boldsymbol{\psi}(\mathrm{mV}) \dagger$ & $\mathbf{p m f}(\mathbf{m V}) \ddagger$ \\
\hline Control $(100 \mathrm{mM} \mathrm{KCl})$ & 1.31 & $-29 \cdot 3$ & $109 \cdot 9$ \\
Lactate $(100 \mathrm{mM}$ potassium lactate $)$ & 0.63 & -63.7 & 102.5 \\
\hline
\end{tabular}

* Measured by the transmembrane equilibration of $\left[{ }^{14} \mathrm{C}\right]$ benzoic acid.

$\dagger$ Measured by the transmembrane equilibration of $\left[{ }^{14} \mathrm{C}\right] \mathrm{TPP}$.

$\ddagger \mathrm{pmf}=\Delta \psi-\mathrm{Z} \Delta \mathrm{pH}$.

simultaneous increase in the $\Delta \psi$ upon the addition of lactate which maintained the pmf of these cells at approximately $-105 \mathrm{mV}$ (Table 2). The pmf values obtained in this study agree well with those found in earlier studies (Dashper \& Reynolds, 1992).

\section{DISCUSSION}

Acidogenicity and acidurance have been proposed as the two major virulence traits of the odontopathogenic bacterium S. mutans (Loesche, 1986). Under conditions of sugar excess lactic acid is the major end-product of glycolysis by $S$. mutans. However the transmembrane movement of the intracellularly produced lactic acid and its effect on $\mathrm{pH}_{\mathrm{i}}$ has received little attention.

Otto et al. $(1980,1982)$ have demonstrated that at neutral $\mathrm{pH}$, lactate transmembrane movement in Lactococcus lactis subsp. cremoris is electrogenic, such that more than one proton is carried across the cell membrane in association with the lactate ion. This process has also been postulated to exist in S. mutans (Keevil et al., 1984).

In this study when a $\Delta \mathrm{pH}$ was imposed upon de-energized cells of $S$. mutans, lactate distributed across the cell membrane in accordance with the equation $\Delta \mathrm{pH}=$ $\log \left([\text { lact }]_{\mathrm{i}} /[\text { lact }]_{\mathrm{o}}\right)$. The efflux of lactate from lactateloaded, de-energized cells produced a $\Delta \mathrm{pH}$ but no $\Delta \psi$. This, and the failure of an imposed $\Delta \psi$ (produced by two distinct methods, giving values of -62 and $-120 \mathrm{mV}$ ) to cause uptake of lactate into de-energized $S$. mutans cells at $\mathrm{pH} 7 \cdot 0$, demonstrates that the transmembrane movement of lactate in $S$. mutans is electroneutral, showing that the undissociated lactic acid is the species excreted. The relationship between [lact $]_{\mathrm{i}}$ and [lact $]_{0}$ and $\Delta \mathrm{pH}$ described in the above equation for de-energized cells was also found in glycolysing cells of $S$. mutans. The demonstration of transmembrane movement of lactic acid in de-energized (ATP-depleted) cells of $S$. mutans negates the necessity for metabolic energy in the translocation of lactate, as proposed recently by Distler et al. (1989).

The results of this study showing the transmembrane movement of lactic acid to be an electroneutral process in S. mutans are consistent with those of Harold \& Levin (1974) and Kobayashi et al. (1982) who demonstrated the electroneutral transmembrane movement of lactic acid in Enterococcus faecalis, and Baronofsky et al. (1984) and Kell et al. (1981) who showed the electroneutral trans- membrane movement of acetic acid in Clostridium thermoaceticum and Clostridium pasteurianum, respectively. Maloney (1983) also concluded that lactic acid transmembrane movement in $L$. lactis glycolysing at $\mathrm{pH} 5 \cdot 0$ was an electroneutral process. However, it has been proposed that some of these acidic end-products are able to passively diffuse across the cell membrane in the uncharged form (Baronofsky et al., 1984; Kell et al., 1981). Due to the high rate of lactic acid production during glycolysis by $S$. mutans, and in view of the polarity of the molecule, it is considered unlikely that the rapid translocation occurs via passive diffusion through the cell membrane (Gatje et al., 1991). The existence of a carrier system for lactic acid in $S$. mutans was indicated in this study by counterflow in the presence of the ionophore gramicidin. This method has been used by other workers to show the existence of membrane carriers for a variety of substrates (Maloney et al., 1975; Gatje et al., 1991 ; Buckley \& Hamilton, 1995).

The enzymic determination of [lact $]_{i}$ and $[\mathrm{lact}]_{0}$ in a suspension of glycolysing $S$. mutans cells allowed the activity of the lactic acid carrier and its effect on $\mathrm{pH}_{\mathrm{i}}$ to be elucidated in energized cells. When glucose was added to de-energized cells of $S$. mutans, lactate accumulated within the cell, indicating that the level of lactic acid was not high enough to allow the carrier to function at a sufficient rate to remove all of the lactate produced by glycolysis. However, as the level of intracellular lactate and lactic acid increased, so the transmembrane lactate chemical potential increased. As the level of intracellular lactate approached $100 \mathrm{mM}$ the transmembrane lactate chemical potential approached $-67 \mathrm{mV}$ and the rate of lactic acid efflux approached the rate of proton extrusion by the cell.

The rate of proton extrusion from $S$. mutans was linear almost immediately after the addition of glucose to the cells. As the lactate concentration increased within the cell during this initial period, the extrusion of protons must be attributed to the activity of the $F_{1} F_{0}$-ATPase. When the [lact $]_{i}$ approached $100 \mathrm{mM}$, the rate of lactic acid efflux increased until all protons and lactate produced by glycolysis were translocated as lactic acid (Fig. 4). The $\mathrm{F}_{1} \mathrm{~F}_{0}$-ATPase therefore appears necessary to establish the $\Delta \mathrm{pH}$ and in so doing allows accumulation of lactate intracellularly, producing a transmembrane lactate gradient or driving force for lactic acid efflux through the carrier. The $\mathrm{F}_{1} \mathrm{~F}_{0}$-ATPase will then only be necessary for 
the maintenance of the $\Delta \mathrm{pH}$ by extruding protons entering the cell in symport with pmf-linked substrates or by unspecified leakage across the cell membrane. This is very important from a bioenergetic point of view, as to extrude all of the protons produced by glycolysis via the $\mathrm{F}_{\mathbf{1}} \mathrm{F}_{\mathbf{0}^{-}}$ ATPase would halve the net production of ATP produced per glucose molecule, assuming a stoichiometry of $2 \mathrm{H}^{+} /$ATP (Mitchell \& Koppenol, 1982).

This scheme of $\mathrm{pH}$ regulation associated with lactic acid efflux is supported by the fact that potassium accumulation is maximal over the first 4 min of glycolysis (Dashper \& Reynolds, 1992), during which time lactate anion is accumulating within the cell. As the $\mathrm{F}_{1} \mathrm{~F}_{0}$-ATPase is extruding protons during this time and lactate anion is accumulating within the cell, the electrogenic uptake of potassium is necessary to dissipate the $\Delta \psi$ created by this process.

This metabolic-energy-independent, carrier-mediated transmembrane movement of lactic acid is an energy efficient way to remove the lactate and protons produced by glycolysis, unless lactate builds up in the extracellular environment. High [lact $]_{0}$ would result in lactic acid being unable to escape from the cell or at even higher concentrations extracellular lactic acid would move down its concentration gradient into the cell, via the carrier, where it would dissociate to lactate and protons, thereby lowering $\mathrm{pH}_{\mathrm{i}}$. Under these conditions the $\mathrm{F}_{1} \mathrm{~F}_{0}$-ATPase would begin to pump the protons out of the cell but would be unable to raise $\mathrm{pH}_{\mathrm{i}}$ back to its initial level due to the large $\Delta \psi$. This $\Delta \psi$ is created by lactic acid movement into the cell, its dissociation and the extrusion of the protons with the resultant intracellular accumulation of negative charge in the form of lactate anions. The $S$. mutans $\mathrm{F}_{1} \mathrm{~F}_{0}$-ATPase is incapable of producing or maintaining a pmf of greater than $-120 \mathrm{mV}$ (Table 2; Dashper \& Reynolds, 1993; Noji et al., 1988). The results of this study are totally consistent with this proposal as the reduction in glycolysis caused by the addition of high [lact $]_{0}$ to $S$. mutans could be attributed to the fall in $\mathrm{pH}_{\mathrm{i}}$. There is no evidence from this study that the intracellular accumulation of lactate per se inhibits glycolysis. Also, as high concentrations of lactate did not result in a decrease in the pmf in glycolysing cells of $S$. mutans, lactate cannot be considered to act as an 'uncoupler' as has been proposed by Baronofsky et al. (1984) and Herrero et al. (1985).

In dense cell suspensions of $S$. mutans, glycolytic activity leads to a rapid increase in lactate concentration outside the cell. This high [lact $]_{0}$ causes a decrease in the $\Delta \mathrm{pH}$, that at acidic $\mathrm{pH}_{\mathrm{o}}$ results in inhibition of glycolysis. Therefore in dental plaque a build up of extracellular lactate may determine the final plaque $\mathrm{pH}$ after a sugar exposure. This may help explain the anticariogenic effect of added calcium lactate reported by Shrestha et al. (1982). Indeed, if the $S$. mutans lactic acid carrier resembles that found in Lactobacillus belveticus (Gatje et al., 1991), as it appears to, then it will also allow equilibration of acetate and other carboxylic acids across the cell membrane, inhibiting glycolytic activity at acidic $\mathrm{pH}$.
In conclusion lactate and protons generated as endproducts of glycolysis in $S$. mutans are translocated across the cell membrane as lactic acid in a carrier-mediated electroneutral process. No input of metabolic energy is necessary for this efflux once a transmembrane lactate chemical potential has been established by the action of the $\mathrm{F}_{1} \mathrm{~F}_{0}-\mathrm{ATPase}$ establishing a $\Delta \mathrm{pH}$. As such this is of great bioenergetic significance to the cell.

\section{ACKNOWLEDGEMENTS}

This investigation was supported in part by a National Health \& Medical Research Council Grant No. 940069

\section{REFERENCES}

Bakker, E. P. \& Harold, F. M. (1980). Energy coupling to potassium transport in Streptococcus faecalis (interplay of ATP and the proton motive force). $J$ Biol Chem 255, 433-440.

Baronofsky, J. J., Schreurs, W. J. A. \& Kashket, E. R. (1984). Uncoupling by acetic acid limits growth of and acetogenesis by Clostridium thermoaceticum. Appl Environ Microbiol 48, 1134-1139.

Buckley, N. D. \& Hamilton, I. R. (1994). Vesicles prepared from Streptococcus mutans demonstrate the presence of a second glucose transport system. Microbiology 140, 2639-2648.

Carlsson, J. (1984). Regulation of sugar metabolism in relation to the feast and famine existence of plaque. In Cariology Today. International Congress Zürich 1983, pp. 205-211. Edited by B. Guggenheim. Basel: Karger.

Carlsson, J. \& Griffith, C. J. (1974). Fermentation products and bacterial yields in glucose-limited and nitrogen-limited cultures of streptococci. Arch Oral Biol 19, 1105-1109.

Cohen, L. H. \& Noell, W. K. (1960). Glucose catabolism of rabbit retina before and after development of visual function. $J$ Neurochem 5, 253-276.

Dashper, S. G. \& Reynolds, E. C. (1990). Characterization of transmembrane movement of glucose and glucose analogs in Streptococcus mutans Ingbritt. J Bacteriol 172, 556-563.

Dashper, S. G. \& Reynolds, E. C. (1992). $\mathrm{pH}$ regulation by Streptococcus mutans. J Dent Res 71, 1159-1165.

Dashper, S. G. \& Reynolds, E. C. (1993). Branched-chain amino acid transport in Streptococcus mutans Ingbritt. Oral Microbiol Immunol 8, 167-171.

Distler, W., Kargermeier, A., Hickel, R. \& Kroncke, A. (1989). Lactate influx and efflux in the 'Streptococcus mutans group' and Streptococcus sanguis. Caries Res 23, 252-255.

Gatje, G., Muller, V. \& Gottschalk, G. (1991). Lactic acid excretion via carrier-mediated diffusion in Lactobacillus belveticus. Appl Microbiol Biotechnol 34, 778-782.

Geddes, D. A. M. (1975). Acids produced by human dental plaque metabolism in situ. Caries Res 9, 98-109.

Hardie, J. M. \& Bowden, G. H. (1976). The microbial flora of dental plaque, bacterial succession and isolation considerations. In Microbial Aspects of Dental Carries, Vol. 3, pp. 63-87. Edited by H. M. Stiles, W. J. Loesche \& T. C. O'Brien. Washington, DC: Information Retrieval Inc.

Harold, F. M. \& Levin, E. (1974). Lactic acid translocation, terminal step in glycolysis by Streptococcus faecalis. J Bacteriol 117, 1141-1148.

Herrero, A. A., Gomez, R. F., Snedecor, B., Tolman, C. J. \& Roberts, M. F. (1985). Growth inhibition of Clostridium thermocellum by carboxylic acids, a mechanism based on uncoupling by weak acids. Appl Microbiol Biotechnol 22, 53-62. 
Horn, H. D. \& Bruns, F. H. (1956). Quantitative bestimmung von $\mathrm{L}(+)$-milchsaure mit milchsauredehydrogenase. Biochim Biophys Acta 21, 378-380.

Keevil, C. W., Williamson, M. I., Marsh, P. D. \& Ellwood, D. C. (1984). Evidence that glucose and sucrose uptake in oral streptococcal bacteria involves independent phosphotransferase and proton-motive force-mediated mechanisms. Arch Oral Biol 29, 871-878.

Kell, C. W., Peck, M. W., Rodger, G. \& Morris, J. G. (1981). On the permeability to weak acids and bases of the cytoplasmic membranes of Clostridium pasteurianum. Biocbem Biophys Res Commun 99, 81-88.

Kelsay, J. L., McCague, K. E. \& Holden, J. M. (1972). Variations in flow rate, metabolites and enzyme activities of fasting human parotid saliva. Arch Oral Biol 17, 304-320.

Kobayashi, H., Murakami, N. \& Unemoto, T. (1982). Regulation of the cytoplasmic $\mathrm{pH}$ in Streptococcus faecalis. J Biol Chem 257, 13246-13252.

Krasse, B. (1966). Human streptococci and experimental caries in hamsters. Arcb Oral Biol 11, 429-436.

Linzer, R. (1976). Serotype polysaccharide antigens of Streptococcus mutans composition and serological cross reactions. In Immunological Aspects of Dental Caries, pp. 91-99. Edited by W'. H. Bowen, R. J. Genco \& T. C. O'Brien. Washington, DC: Information Retrieval Inc.

Loesche, W. J. (1986). Role of Streptococcus mutans in human dental decay. Microbiol Rev 50, 353-380.

Maloney, P. C. (1983). Relationship between phosphorylation potential and electrochemical $\mathrm{H}^{+}$gradient during glycolysis in Streptococcus lactis. J Bacteriol 153, 1461-1470.

Maloney, P. C., Kashket, E. R. \& Wilson, T. R. (1975). Methods for studying transport in bacteria. Methods Membr Biol 5, 1-50.

Michels, P. A. M., Michels, J. P. J., Boonstra, J. \& Konings, W. N. (1979). Generation of electrochemical proton gradient in bacteria by excretion of metabolic end-products. FEMS Microbiol Lett $\mathbf{5}$, 357-362.
Mitchell, P. (1963). Molecule, group and electron translocation through natural membranes. Biochem Soc Symp 22, 142-168.

Mitchell, P. \& Koppenol, W. H. (1982). Chemiosmotic ATPase mechanisms. Ann NY Acad Sci 402, 584-601.

Noji, S., Sato, Y. \& Taniguchi, S. (1988). Effect of intracellular $\mathrm{pH}$ and potassium ions on a primary transport system for glutamate/ aspartate in Streptococcus mutans. Eur J Biochem 175, 491-495.

Otto, R., Sonnenberg, A. S. M., Veldkamp, H. \& Konings, W. N. (1980). Generation of an electrochemical proton gradient in Streptococcus cremoris by lactate efflux. Proc Natl Acad Sci USA 77, $5502-5506$

Otto, R., Lageveen, R. G., Veldkamp, H. \& Konings, W. N. (1982). Lactate efflux-induced electrical potential in membrane vesicles of Streptococcus cremoris. J Bacteriol 149, 733-738.

Shrestha, B. M., Mundorff, S. A. \& Bibby, B. G. (1982). Preliminary studies on calcium lactate as an anticaries food additive. Caries Res $16,12-17$.

Tanzer, J. M., Krichevsky, M. I. \& Keyes, P. H. (1969). The metabolic fate of glucose catabolized by a washed stationary phase caries-conducive Streptococcus. Caries Res 3, 167-177.

ten Brink, B. \& Konings, W. N. (1980). Generation of an electrochemical proton gradient by lactate efflux in membrane vesicles of Escherichia coli. Eur J Biochem 111, 59-66.

Yamada, T. (1987). Regulation of glycolysis in streptococci. In Sugar Transport and Metabolism on Gram-positive Bacteria, pp. 66-93. Edited by J. Reizer \& A. Peterofsky. Chichester: Ellis Horwood Ltd.

Yamada, T. \& Carlsson, J. (1975). Regulation of lactate dehydrogenase and change of fermentation products in Streptococci. $J$ Bacteriol 124, 55-61.

Received 19 May 1995; revised 15 August 1995; accepted 12 September 1995. 